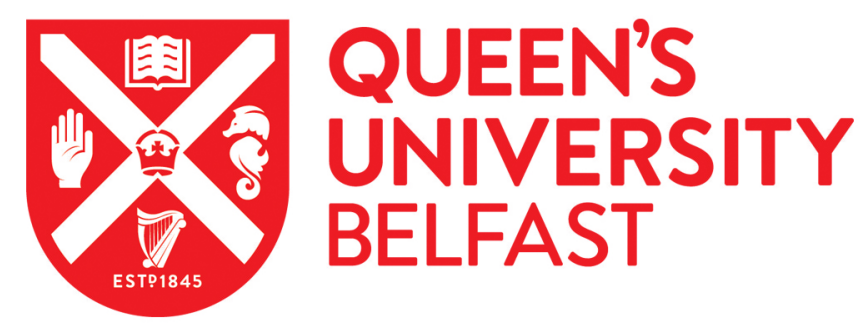

\title{
Laves-phase in the China Low Activation Martensitic steel after long- term creep exposure
}

Huang, L., Hu, X., Yan, W., Sha, W., Xiao, F., Shan, Y., \& Yang, K. (2014). Laves-phase in the China Low Activation Martensitic steel after long-term creep exposure. Materials and Design, 63, 333-335.

https://doi.org/10.1016/j.matdes.2014.06.028

Published in:

Materials and Design

Document Version:

Peer reviewed version

Queen's University Belfast - Research Portal:

Link to publication record in Queen's University Belfast Research Portal

\section{Publisher rights}

This is the author's version of a work that was accepted for publication in Materials \& Design. Changes resulting from the publishing process, such as peer review, editing, corrections, structural formatting, and other quality control mechanisms may not be reflected in this document. Changes may have been made to this work since it was submitted for publication. A definitive version was subsequently published in Materials \& Design, volume 63, November 2014, DOI 10.1016/j.matdes.2014.06.028

\section{General rights}

Copyright for the publications made accessible via the Queen's University Belfast Research Portal is retained by the author(s) and / or other copyright owners and it is a condition of accessing these publications that users recognise and abide by the legal requirements associated with these rights.

Take down policy

The Research Portal is Queen's institutional repository that provides access to Queen's research output. Every effort has been made to ensure that content in the Research Portal does not infringe any person's rights, or applicable UK laws. If you discover content in the Research Portal that you believe breaches copyright or violates any law, please contact openaccess@qub.ac.uk. 
Short Communication

First author: Lixin Huang

Email addresses: 1xhuang@ysu.edu.cn

*Corresponding author: Ke Yang

Email addresses: kyang@imr.ac.cn

Corresponding author addresses: Institute of Metal Research, Chinese Academy of Sciences, 72 Wenhua Road,

Shenyang, China 110016 Tel.:+86 2423971628 Fax: +86 2423971628

\section{Laves-phase in the China Low Activation Martensitic steel after long-term creep exposure}

Lixin Huang ${ }^{\mathrm{a}, \mathrm{b}}$, Xue Hu ${ }^{\mathrm{b}, \mathrm{c}}$, Wei Yan ${ }^{\mathrm{b}}$, Wei Sha ${ }^{\mathrm{d}}$, Furen Xiao ${ }^{\mathrm{a}}$, Yiyin Shan ${ }^{\mathrm{b}}$, Ke Yang ${ }^{\mathrm{b}, *}$

${ }^{\text {a }}$ State Key Laboratory of Metastable Materials Science and Technology, Yanshan University, Qinhuangdao 066004, China

${ }^{\mathrm{b}}$ Institute of Metal Research, Chinese Academy of Sciences, Shenyang 110016, China

${ }^{\mathrm{c}}$ University of Chinese Academy of Sciences, 19 Yuquan Road, Beijing 100049, China

${ }^{\mathrm{d}}$ School of Planning, Architecture \& Civil Engineering, Queen's University Belfast, Belfast BT9 5AG, UK

\section{Abstract}

Creep test at $600{ }^{\circ} \mathrm{C}$ under $130 \mathrm{MPa}$ for the China Low Activation 
Martensitic (CLAM) steel was performed up to $7913 \mathrm{~h}$ in this study. According to the stress level, the crept specimen was divided into three regions in order to investigate the influence of stress on Laves-phase formation. In addition to the expected $\mathrm{M}_{23} \mathrm{C}_{6}$ carbide and $\mathrm{MX}$ carbonitride, the amount and the size of Laves phase in these three regions on the crept specimen were characterized by transmission electron microscopy. Laves phase could be found in all the regions and the creep stress could promote the formation of Laves phase.

Keywords: China Low Activation Martensitic steel; Creep-rupture; Laves phase; Creep stress

\section{Introduction}

During the past 40 years, reduced activation ferritic/martensitic (RAFM) steels such as F82H [1], Eurofer97 [2], 9Cr2WVTa and its variants $[3,4,5]$ and the China Low Activation Martensitic (CLAM) [6] have been developed in Japan, Europe, US and China, respectively. They are promising candidate materials for first wall and blanket structural application in the future fusion reactors [7]. The precipitates were identified as an important cause of the microstructure instabilities associated with the long-term creep of these high $\mathrm{Cr}$ steels $[8,9]$. In addition to $\mathrm{M}_{23} \mathrm{C}_{6}$-type $(\mathrm{M}=\mathrm{Fe}, \mathrm{Cr}, \mathrm{W})$ carbide and $\mathrm{MX}$-type $(\mathrm{M}=\mathrm{V}$, Ta; $\mathrm{X}=\mathrm{C}, \mathrm{N})$ carbonitride in the tempered RAFM steel $[2,10], \mathrm{Fe}_{2} \mathrm{~W}$ Laves 
phase precipitates are also significant to creep. Conventionally, Laves phase is often considered to influence the microstructure and mechanical properties of those steels $[11,12]$. The precipitation of Laves phase with small size should effectively decrease the minimum creep rate, which could compensate the loss of solid solution strengthening at the early stage. However, the later growth and coarsening of $\mathrm{Fe}_{2} \mathrm{~W}$ would accelerate the creep rate after reaching the minimum creep rate, failing to compensate that loss $[13,14]$. However, up to now, precipitation behavior of Laves phase during long term creep exposure has rarely been reported in literature.

The purpose of the present work is to investigate the precipitation behavior of Laves phase in the CLAM steel during long term creep at elevated temperature. The emphasis is on the nucleation, growth and morphology of the Laves phase influenced by the creep stress.

\section{Experimental details}

The chemical composition of the CLAM steel in the present study was, in wt. $\%, 0.091 \% \mathrm{C}, 8.93 \% \mathrm{Cr}, 0.49 \% \mathrm{Mn}, 1.51 \% \mathrm{~W}, 0.15 \% \mathrm{~V}$, $0.15 \% \mathrm{Ta}$, and $\mathrm{Fe}$ in balance. The CLAM steel plate was heat treated by normalizing at $980{ }^{\circ} \mathrm{C}$ for $30 \mathrm{~min}$ and tempering at $760{ }^{\circ} \mathrm{C}$ for $90 \mathrm{~min}$. Then, specimens with $5 \mathrm{~mm}$ gauge diameter and $67 \mathrm{~mm}$ gauge length were machined from the tempered plate with the axis parallel to the 
rolling direction.

Creep-rupture test was conducted in air at $600{ }^{\circ} \mathrm{C}$ under $130 \mathrm{MPa}$. The crept specimen after creep fracture was divided into three regions, the necking down region (region A), the uniform plastic deformation region (region $\mathrm{B}$ ) and the clamp region (region $\mathrm{C}$ ). Region $\mathrm{A}$ was near the creep fracture surface with large deformation, region B had uniform plastic deformation and region $\mathrm{C}$ was the part of clamp segment of the crept specimen under low stress during the creep rupture test. Therefore, region $\mathrm{C}$ was considered as the aging region. Figure 1 shows the three different regions of a crept specimen.

The microstructures of the different regions on the crept specimen were characterized by using a transmission electron microscope (TEM). The thin foils for the TEM observation were cut from the creep specimens along the transverse cross-section, and then electrochemically polished in a solution of $10 \%$ perchloric acid and $90 \%$ acetic acid at $11-15^{\circ} \mathrm{C}$ and $28-30 \mathrm{~V}$.

\section{Results}

Figure 2 shows the microstructure of the presently studied CLAM steel before the creep test. The microstructure of CLAM steel was tempered martensite after the heat treatment. $\mathrm{M}_{23} \mathrm{C}_{6}$ carbide and $\mathrm{MX}$ carbonitride were the main precipitates present in the microstructure. The 
$\mathrm{M}_{23} \mathrm{C}_{6}$ carbide was precipitated at the prior austenite grain boundaries, as well as along the subgrains and lath boundaries. The primary morphology of $\mathrm{M}_{23} \mathrm{C}_{6}$ precipitates mainly includes rod-shaped and spherical, and the average size is about $80 \mathrm{~nm}$. MX carbonitride was formed within the subgrains with size of about $20-40 \mathrm{~nm}$. Laves phase was not detected after the heat treatment.

The crept specimen at $600{ }^{\circ} \mathrm{C}$ under $130 \mathrm{MPa}$ for the duration of $7913 \mathrm{~h}$ was chosen for study. With varying distance from crept fracture, the lath martensite in CLAM steel showed different degrees of recovery and recrystallization.

The size of $\mathrm{M}_{23} \mathrm{C}_{6}$ precipitates in the crept specimen was larger than that in the tempered steel. The presence of Laves phase in the crept specimen was investigated by TEM. Using the results of the microstructural study, the regions had the following features:

(i) For region $\mathrm{C}$ (Figure 3c), this part of the crept specimen was little affected by the creep stress. The morphology of martensite in this part was observed by TEM. The width of martensite lath in region $\mathrm{C}$ was about $0.62 \mu \mathrm{m}$. The Laves precipitates in this region could reach large dimensions, with average diameter of about $0.32 \mu \mathrm{m}$.

(ii) For region B (Figure 3b), the width of the martensite lath and fragmentation of subgrain were observed. Meanwhile, the Laves phase was smaller than that in region $\mathrm{C}$, but the number was larger than that in 
region $\mathrm{C}$.

(iii) For region A (Figure 3a), the CLAM steel was characterized by its fine subgrain structure with a high density of free dislocations within the subgrains. Compared to regions $\mathrm{B}$ and $\mathrm{C}$, the average size of Laves phase was the smallest, but the amount of Laves phase was the largest.

Meanwhile, precipitates of MX were found to be highly resistant to coarsening during the creep.

\section{Discussion}

In this work, the crept specimen of CLAM steel was divided into three regions, and Laves phase precipitation in each region was studied by microstructural observation.

In the tempered CLAM steel, there were only two types of precipitates in the matrix, $\mathrm{M}_{23} \mathrm{C}_{6}$ carbide and $\mathrm{MX}$ carbonitride. The Laves phase, which would occur during the long-term creep exposure, did not appear. In our previous work $[10,15]$, the precipitation of Laves phase appeared in the steel matrix after aging at $600{ }^{\circ} \mathrm{C}$ for $1100 \mathrm{~h}$. In the present study, the specimen of CLAM steel was crept at $600{ }^{\circ} \mathrm{C}$ under 130 MPa for duration of $7913 \mathrm{~h}$, and the precipitation of Laves phase could be observed in all the three regions on the crept specimen. It has been found that Laves phase nucleated mostly at martensitic lath boundaries [16], subgrain boundaries and prior austenitic grain boundaries [17]. The 
number and size of Laves phase were different in three regions on the crept specimen.

Region $\mathrm{C}$ was the part of the crept specimen under low stress, which was regarded as an aged region. The width of martensite lath increased compared with that in the tempered steel, but the feature of martensite lath was kept. The addition of $\mathrm{W}$ in the steel could slow down the growth of lath width and the annihilation of dislocations in lath interior [16].

The new phase (Laves phase) would nucleate at grain boundaries by consuming the $\mathrm{W}$ element around it and hence decreased the concentration of $\mathrm{W}$, resulting in a reduction of the phase transformation free energy, which would raise the critical nucleation energy and reduce the nucleation rate. Though the tempered martensitic lath structure would be stable at the elevated temperatures without stress, its recovery took place substantially during the creep [16]. The dislocation density decreased and the subgrains grew during the creep of 9-12\% $\mathrm{Cr}$ steels under suitable ranges of stress and temperature [18]. The creep stress could accelerate the microstructural evolution, including the recovery of excess dislocations and the growth of martensite lath subgrains.

The dragging effect on dislocations by $\mathrm{W}$ atoms under stress was considered to be one of important factors for the enhancement of precipitation and growth of the Laves phase [19]. The dragged dislocations could provide the nucleation sites for the Laves phase. The 
growth rates of Laves phase in regions A and B were much lower than that in region C. It was ascribed to the fast nucleation of Laves phase, which consumed much $\mathrm{W}$ in solid solution and resulted in the decrease of W concentration. Then the Laves phase would grow slowly with low W concentration. However, when the rate of $\mathrm{W}$ atom diffusion is increased by high temperature, Laves phase in the region affected by stress might grow faster compared to other regions. This effect was confirmed in a recent paper in another steel of the heat-resistant type [20].

\section{Conclusions}

The crept CLAM steel at $600{ }^{\circ} \mathrm{C}$ under a constant load of $130 \mathrm{MPa}$ for $7913 \mathrm{~h}$ was investigated. The crept specimen was divided into three regions according to the different stress levels. The creep stress could enhance the microstructure recovery. Laves phase was found in all the regions on the crept specimen, but showed different features along the length of crept specimen. Compared with the region under low stress, the density of Laves phase was high, while its average size was small near the neck down region. The creep stress enhanced the formation of Laves phase during creep due to the acceleration of nucleation rate of Laves phase under creep stress in the early stage. 


\section{Acknowledgements}

This study was supported by the ITER Program (No. 2009GB109002), Chinese Academy of Sciences Knowledge Innovation Program (KJCX2-YW-N35), and the National Natural Science Foundation of China (No. 51271175).

\section{References}

[1] Jitsukawa S, Tamura M, van der Schaaf B, Klueh RL, Alamo A, Petersen C, et al. Development of an extensive database of mechanical and physical properties for reduced-activation martensitic steel F82H. J Nucl Mater 2002;307:179-86.

[2] Fernandez P, Lancha AM, Lapena J, Serrano M, Hernandez-Mayoral M. Metallurgical properties of reduced activation martensitic steel Eurofer'97 in the as-received condition and after thermal ageing. J Nucl Mater 2002;307:495-9.

[3] Materna-Morris EI, Rieth M, Ehrlich K. Mechanical properties and microstructure of HFR-irradiated ferritic/martensitic low-activation alloys. In: Hamilton ML, Kumar AS, Rosinski ST, Grossbeck ML, editors. Effects of radiation on materials: 19th International Symposium, W Conshohocken: American Society for Testing and Materials; 2000, p. 597-611.

[4] Yan P, Liu Z, Bao H, Weng Y, Liu W. Effect of tempering temperature on the toughness of 9Cr-3W-3Co martensitic heat resistant steel. Mater Des 2014;54:874-9.

[5] Wang SS, Peng DL, Chang L, Hui XD. Enhanced mechanical properties induced by refined heat treatment for $9 \mathrm{Cr}-0.5 \mathrm{Mo}-1.8 \mathrm{~W}$ martensitic heat resistant steel. Mater 
Des 2013;50:174-80.

[6] Huang Q, Li C, Li Y, Chen M, Zhang M, Peng L, et al. Progress in development of China low activation martensitic steel for fusion application. J Nucl Mater 2007;367:142-6.

[7] Klueh RL. Reduced-activation steels: Future development for improved creep strength. J Nucl Mater 2008;378:159-66.

[8] Ghassemi Armaki H, Chen R, Maruyama K, Igarashi M. Creep behavior and degradation of subgrain structures pinned by nanoscale precipitates in strength-enhanced 5 to 12 pct $\mathrm{Cr}$ ferritic steels. Metall Mater Trans A 2011;42:3084-94.

[9] Yin FS, Jung WS, Chung SH. Microstructure and creep rupture characteristics of an ultra-low carbon ferritic/martensitic heat resistant steel. Scripta Mater 2007;57:469-72.

[10] Huang L, Hu X, Yang C, Yan W, Xiao F, Shan Y, et al. Influence of thermal aging on microstructure and mechanical properties of CLAM steel. J Nucl Mater $2013 ; 443: 479-83$.

[11] Ishii T, Fukaya K, Nishiyama Y, Suzuki M, Eto M. Low cycle fatigue properties of $8 \mathrm{Cr}-2 \mathrm{WVTa}$ ferritic steel at elevated temperatures. $\mathrm{J}$ Nucl Mater $1998 ; 258-263: 1183-6$.

[12] Kunimitsu S, You Y, Kasuya N, Sasaki Y, Hosoi Y. Effect of thermo-mechanical treatment on toughness of $9 \mathrm{Cr}-\mathrm{W}$ ferritic-martensitic steels during aging. $\mathrm{J}$ Nucl Mater 1991;179-181:689-92. 
[13] Abe F. Creep rates and strengthening mechanisms in tungsten-strengthened $9 \mathrm{Cr}$ steels. Mater Sci Eng A 2001;319-321:770-3.

[14] Lee JS, Armaki HG, Maruyama K, Muraki T, Asahi H. Causes of breakdown of creep strength in 9Cr-1.8 W-0.5 Mo-VNb steel. Mater Sci Eng A 2006;428:270-5.

[15] Hu X, Huang L, Yan W, Wang W, Sha W, Shan Y, et al. Evolution of microstructure and changes of mechanical properties of CLAM steel after long-term aging. Mater Sci Eng A 2013;586:253-8.

[16] Sawada K, Takeda M, Maruyama K, Ishii R, Yamada M, Nagae Y, et al. Effect of $\mathrm{W}$ on recovery of lath structure during creep of high chromium martensitic steels. Mater Sci Eng A 1999;267:19-25.

[17] Panait CG, Bendick W, Fuchsmann A, Gourgues-Lorenzon AF, Besson J. Study of the microstructure of the Grade 91 steel after more than $100,000 \mathrm{~h}$ of creep exposure at $600{ }^{\circ} \mathrm{C}$. Int J Pres Ves Pip 2010;87:326-35.

[18] Hald J, Korcakova L. Precipitate stability in creep resistant ferritic steels: experimental investigations and modelling. ISIJ Int 2003;43:420-7.

[19] Cui J, Kim IS, Kang CY, Miyahara K. Creep stress effect on the precipitation behavior of Laves phase in Fe-10\% Cr-6\% W alloys. ISIJ Int 2001;41:368-71.

[20] Nie M, Zhang J, Huang F, Liu JW, Zhu XK, Chen ZL et al. Microstructure evolution and life assessment of T92 steel during long-term creep. J Alloy Compd 2014;588:348-56. 
Figure captions

Figure 1. Sketch of different regions in a crept specimen. Dimension in milimetres.

Figure 2. Microstructure of the tempered CLAM steel observed on TEM.

Figure 3. Microstructures of three regions of crept specimen. (a) Region $\mathrm{A}$; (b) region $\mathrm{B}$; (c) region $\mathrm{C}$; (d) electron diffraction patterns of Laves phase. 


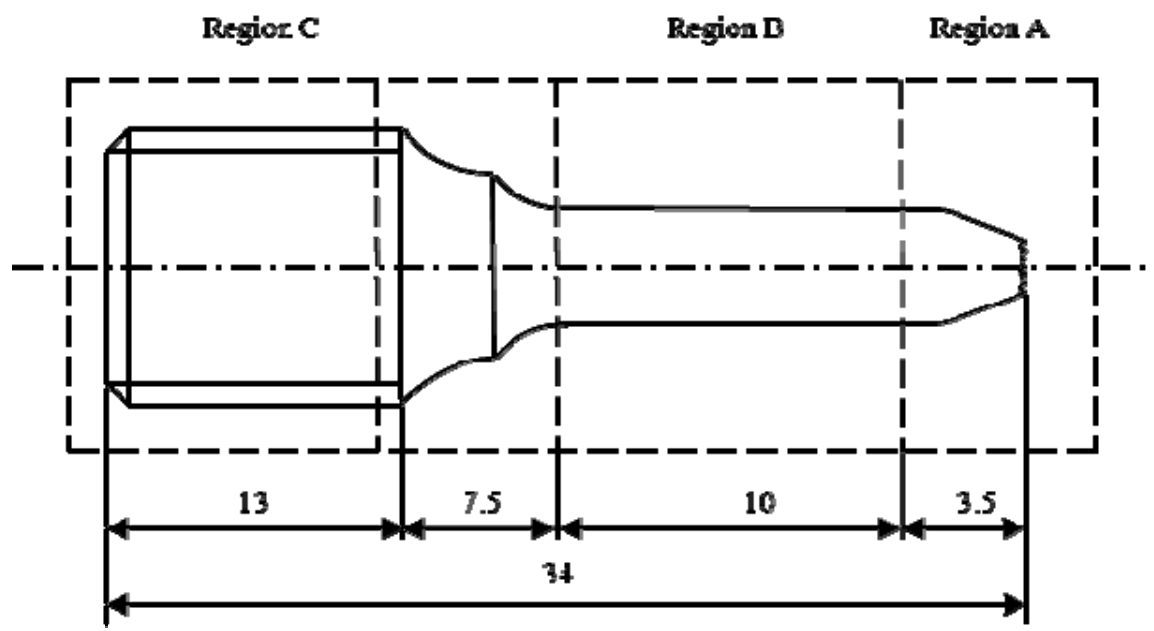

Figure 1. Sketch of different regions in a crept specimen. Dimension in milimetres. 


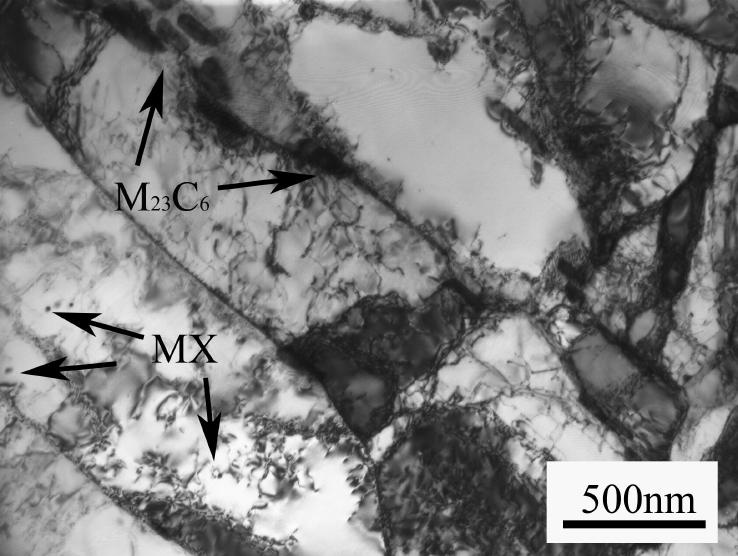



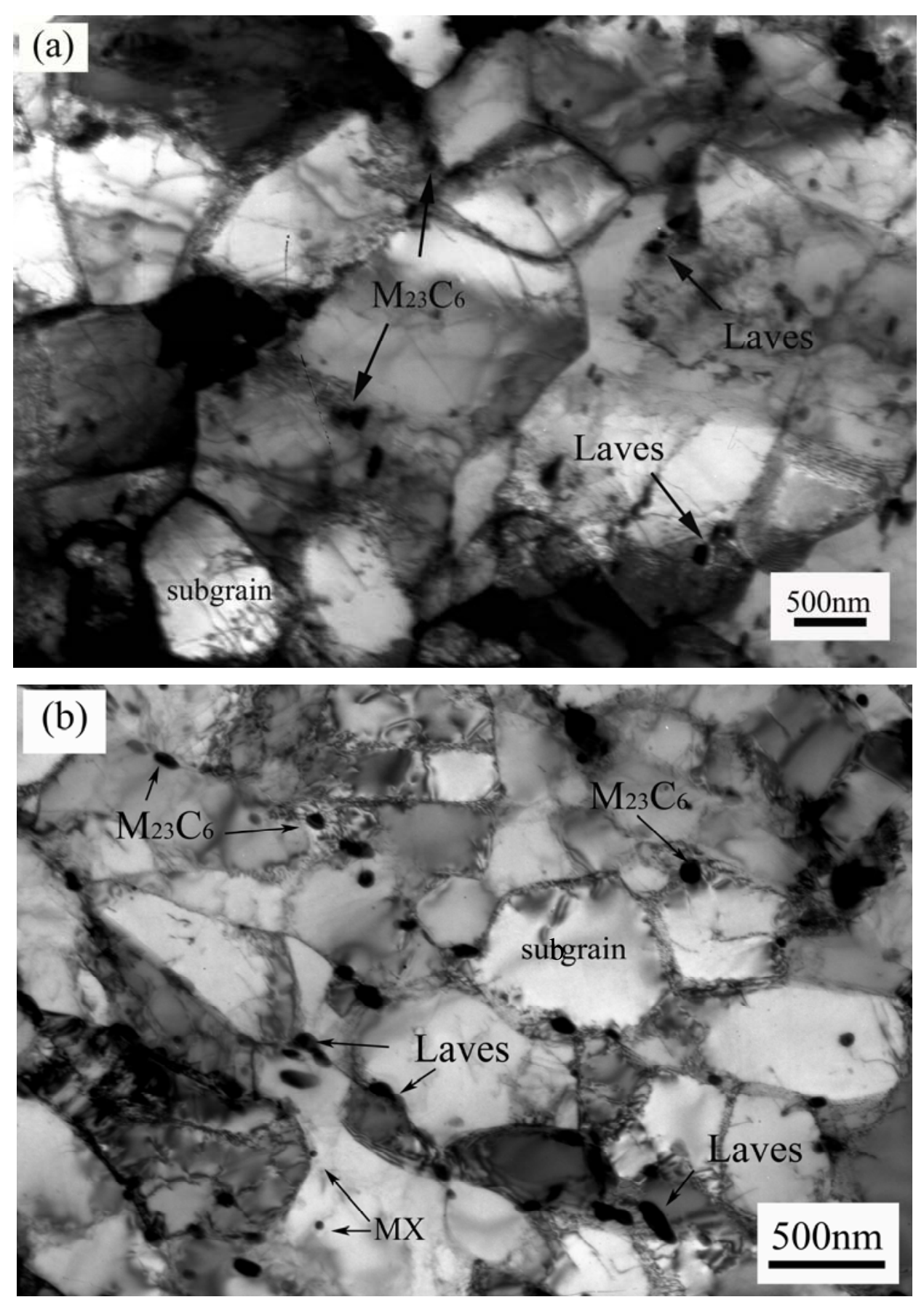

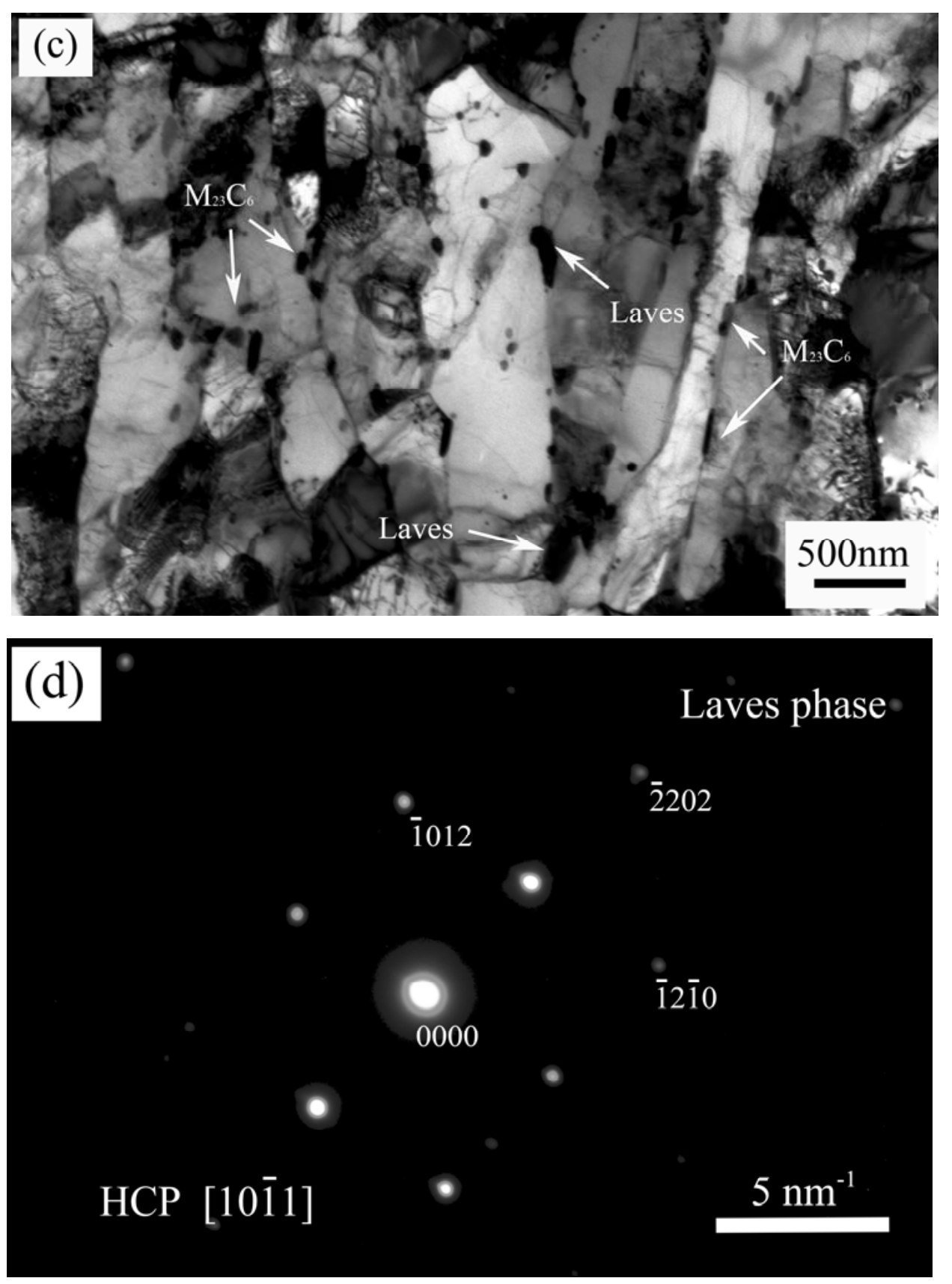

Figure 3. Microstructures of three regions of crept specimen. (a) Region A; (b)

region $\mathrm{B}$; (c) region $\mathrm{C}$; (d) electron diffraction patterns of Laves phase. 